\title{
How does access to development finance shape our cities?
}

\author{
Eddo Coiacetto, Discipline of Urban and Environmental Planning, Griffith University, \\ e.coiacetto@griffith.edu.au \\ Lyndall Bryant, Property and Planning, Queensland University of Technology, lyndall.bryant@qut.edu.au
}

\begin{abstract}
In market economies the built environment is largely the product of private sector property development. Property development is a high-risk entrepreneurial activity executing expensive projects with long gestation periods in an uncertain environment and into an uncertain future. Risk lies at the core of development: the developer manages the multiple risks of development and it is the capital injection and financing that is placed at risk.
\end{abstract}

From the developer's perspective the search for development capital is a quest: to access more finance, over a longer term, with fewer conditions and at lower rates. From the supply angle, capital of various sources - banks, insurance companies, superannuation funds, accumulated firm profits, retail investors and private equity - is always seeking above market returns for limited risk. Property development presents one potentially lucrative, but risky, investment opportunity. Competition for returns on capital produces a continual dynamic evolution of methods for funding property developments. And thus the relationship between capital and development and the outcomes for the built environment are in a restless continual evolution.

Little is documented about the ways development is financed in Australia and even less of the consequences for cities. Using publicly available data sources and examples of different development financing from Australian practice, this paper argues that different methods of financing development have different outcomes and consequences for the built environment. This paper also presents an agenda for further research into these themes.

\section{Purpose}

This paper argues that different methods of financing development have different outcomes and consequences for the built environment. Development finance is not an indifferent agent in shaping cities: this paper proposes that in different stages of the economic cycle, the availability of finance (or lack thereof) can determine which types and scale of developments can proceed and which do not. Our purpose is not to deliver a comprehensive account of the different sources and forms of finance available in Australia and how those different forms and sources have shaped Australian cities: that formidable empirical undertaking is beyond the scope of one paper. As we indicate, this is not documented in the literature. Moreover, the situation is a dynamic one changing over time. Such a study is needed for a better understanding of the forces which shape Australian cities.

Our argument is made by a small number of illustrations of different development financing from Australian practice. We utilise a variety of publicly available data sources (often plagued by inconsistent or incorrect use of financial terminology); scholarly literature where available; and our experience of and liaison with the development and finance industries including 15 years experience in these industries and over 15 years of guest lectures from the development finance sub-sector.

The paper begins with a brief overview of development and of finance and of the connection between the two. The next section concerns the ways in which the literature deals with the connection between development finance and built environment outcomes. Then, in the main part of the paper, attention turns to Australia focusing on number of different sources of finance - banks, superannuation funds, debenture lenders and mortgage trusts, development funds, and private equity - and considering, in turn, how each of these may impact differently on the built environment. The conclusions briefly summarize these before presenting an agenda for research into these themes.

\section{Development and Finance}

In market economies the built environment is largely the product of private sector property development. Private sector developers dominate residential, retail, commercial and industrial space production in Australia. The products range in scale from one or two allotments through to entire new towns - mixed use master planned communities with target populations in the hundreds of thousands. The producers comprise 
a variety of operators of diverse scales, natures and modus operandi and for whom the commercial incentive is the prime driver (Adams, 1994; Adams, Croudace \& Tiesdell, 2012; Coiacetto, 2001; Coiacetto, 2007). While public sector agencies actively develop in four states and one territory, these in recent years have experienced a reorientation of their agenda towards commercial objectives and away from the broader social purposes of their establishment in the 1970s (Gleeson \& Coiacetto, 2007). Local governments are responsible for a fraction of the development in various sectors including industrial space in locations where the market is too small or unreliable to attract private sector developers (Coiacetto \& Baker, 2006). Not for profit organizations and housing corporations supply affordable housing product for eligible consumers, with a longer term outlook and lower commercial benchmarks (Sharam, McShane, Alves, Bryant \& Shihab-Smith, in review).

Development is a high-risk entrepreneurial activity executing expensive projects with long gestation periods in an uncertain environment and into an uncertain future. Development is considered a special industry whose unique nature is partly attributable to the unique nature of property (Zell, 1986, 1 in Logan 1993) with its imperfect and inefficient markets. Since each property is unique - its location, age, accessibility, tenure, existing uses and consents, state of development and development potential and so on - and there are few buyers in almost all sub-markets, there is no true market value of a property: the market only determines a price range (Adams, 1994, pp. 12-37; Evans, 1995, p. 5). It is in this context that

"buyer and seller psychology affects prices, that time on the market matters, and that real estate agents have a role to play in channeling information but, at the same time, have increased opportunities to act unethically and illegally" (Evans 1995, p. 5).

Development is thus characterised by secrecy and secretive negotiations with transactions often made by intermediaries (Adams, 1994, pp. 12-69) and a decision making environment which is dynamic, multidirectional, unstable, and characterised by interrelated and unique business forces. Information is scanty and poor, forecasting is difficult, time is critical because opportunities are fleeting, and competition is strong. Uncertainty surrounds matters such as site conditions; community reactions or opposition; infrastructure capacity and requirements; planning, engineering and building requirements and approvals; and construction delays. Partly because of industrial secrecy, it is difficult for developers to predict supply for a market which exists not when they initiate the development, but one hoped will exist at a future time when the development products come on stream, which may be many years into the future. And so the industry is characterised by booms and busts. Developers must rush into decisions which bind them to set courses in which they irreversibly commit large amounts of equity and other financial resources to projects in an uncertain future (Whitehead, 1987, p. 15) to produce high value products: The sale price of even one small development product, namely a single residential lot in Australia, might be in the order of $\$ 300,000$.

Each project is a stand-alone production in an ever-shifting context (market, planning, surrounding infrastructure and built environment, economy, finance) requiring a unique assemblage and management of resources: an industry more akin to a movie production than manufacturing or construction (Fainstein, 2001). Developers operate in an unstable, dynamic competitive arena: a complex, shifting array of numerous heterogeneous players of diverse capacity entering and leaving the industry through economic cycles and over longer time frames (Adams, Croudace \& Tiesdell, 2012).

Development finance differs from other forms of property lending, in that the asset upon which the loan is secured, is yet to be constructed, and there is no income generated throughout the development process to service the loan. Funding must be provided throughout the development process - i.e. acquisition, design, statutory approvals, marketing, construction and sale/leasing. This is in contrast to a loan for an income producing property where the property is complete and generating sufficient income to at least service interest payments (Bryant, 2012).

And so, in short, risk lies at the core of development: the developer manages the multiple risks of development. And it is the capital injection and/or financing that is placed at risk. But high-risk makes attracting the significant amounts of necessary capital a challenge: a quest to attract finance at affordable rates, at acceptable conditions and for a sufficient term to execute a project or projects. Because of its inherent risks, development traditionally has been a local industry which favours players with local contacts, particularly in government, and local knowledge of market conditions (Logan, 1993). Traditionally, local players borrowed from institutions at above average rates of interest, on a project-by-project basis, for short terms and subject to onerous conditions, with frequent inspections and site visits (see Rudin, 1978, pp. 11- 
28). From the developer's perspective the search for development capital is a quest: to access more finance, over a longer term, with fewer conditions and at lower rates.

From the supply angle, capital of various sources - banks, insurance companies, superannuation funds, accumulated firm profits, retail (small or individual) investors and private equity - is always seeking above market returns for limited risk. Development presents one potentially lucrative, but risky, investment opportunity. Generally, developers tend to be optimistic while lenders cautious (eg Ratciffe et al. 2009, p. 461), something particularly evident through dampening development cycles as lenders and investors become jittery at first signs of recession or other economic trouble.

Competition for returns on capital produces a continual dynamic evolution of methods of funding property developments. And thus the relationship between capital and development (and, as a consequence, the outcomes for the built environment) are in a restless continual evolution.

It is appropriate to provide some clarification around the term capital. It means "money", and in the context of property development and the investment universe it could be debt or equity. Bryant (2012) provides a useful description of the characteristics of debt and equity. In essence, debt is the cheapest form of borrowing as it secured in some form. There is the expectation by the lender that the principle will be repaid, together with the nominated interest at the end of the loan term. The lenders rights to be repaid are legally secured generally by way of registered mortgage. In contrast, equity is the most expensive form of borrowing as the investment is fully at risk. Unless there is misrepresentation or some other fraud proven on behalf of the borrower, should a project fail an equity investor has no legal recourse other than what is provided in the loan documents to repayment of the invested funds let alone any promised return. Hybrid capital products have evolved that blend the characteristics of debt and equity in order to attract investment.

Logan (1993) provides an account of the evolution of new forms of raising cheaper long-term capital for development on a global market and of the growth of new types of financial intermediaries to channel capital from a growing range of investors to development. This limited globalisation of development was accompanied by the emergence of new types of larger and international scale development corporations at times blurring the distinction between developer and financier. The changes in financing, under the umbrella term 'securitisation', were facilitated by investment risk rating services. The effect was to distance the investor from the property or project risk in an industry where local factors, local knowledge and an attention to detail are critical.

In summary, Ratcliffe et al. (2009, pp. 430-68) make several pertinent points about the financing of property development:

- property development finance is a subject of increasing complexity

- it is not an area that lends itself to generalisation: there are many ways to finance development from a wide range of institutions. "It can almost be said that every deal dictates its own terms" (p. 430)

- the approaches are in continual evolution

- the status of the developer and the risk of projects affects their options and choices

- developers should, and many do, use multiple means and sources of funding developments.

\section{Development Finance and the Built Environment in the Literature}

The connections between finance and built environment outcomes arise in the literature in several ways. Most generally, capital flows have been linked to economic changes and subsequently the nature of the urban built environment. Harvey (1978 \& 1985) theorised development and urbanisation occurring in bursts: a by-product of capital switches enabled during upswings in the general economy. Capital, as various forms of savings, accumulates during an economic upturn and is invested in the most profitable industry sectors. However, as more entrepreneurs are attracted to those industries increasing supply, profits decline and investment is switched to peripheral and more speculative and high risk ventures such as third world investment and property development. Such capital accumulations resulting from deficit funding of the Vietnam War combined with OPEC oil price rises were thought to have produced Sydney's 1970s development boom (Daly, 1982). Conversely, Beauregard (1994), found little empirical evidence for capital switching during the 1980s US building boom.

McKenzie's account of common interest developments in the US provides one illustration of how access to non-traditional sources of capital - equity capital rather than debt - shaped built environment outcomes in the 1960s (1994, pp. 98-110). These large scale developments were beyond the capacity, resources and riskreach of even the largest developer-builders of the time. These privatised "instant cities" of hundreds of 
thousands of residents became possible because they were built and/or financed by large industrial corporations, such as Gulf Oil, Goodyear, Westinghouse and General Electric, entering the development arena with access to vast amounts of stock market equity and trading debt.

Daly (1982) examined changes in financing amongst other international forces (global migration, international movements of capital,) and local influences (planning policies, mineral booms) on the growth of Sydney and other Australian cities between 1850 and 1981. These influenced the boom-bust nature of development in those cities, their urban landscapes and the scale of developers involved. New financial institutions - building societies and those issuing debentures and unsecured notes - fuelled Sydney's 196874 boom. Significantly, the latter institutions exacerbated the boom resulting in overbuilding, sprawl, price collapses and other consequential "bust" impacts. This occurred due to restructuring of the development industry attracting inexperienced players to the more speculative end of the industry: firstly, the semiprofessionals surrounding development, such as solicitors and estate agents; then the rich amateurs, doctors, dentists and businessmen; and then finally many others including con-men, farmers and ordinary citizens. Moreover, as repeated in the 2000s, "the boom was financed significantly by bodies largely outside the ambit of government control" (Daly, 1982, p.3).

Many financiers are intermediaries channelling various forms of savings from retail and wholesale lenders/investors to developers. Ratcliffe et al. (2009, pp. 430-468) overview the various sources (and types) of finance for development in the UK discussing the risks and benefits of each for the developer. Each source is likely to impact the developers' decision-making process in relation to the built product and hence potentially the impact on the built environment. According to Ratcliffe et al. (2009) the sources include:

- insurance companies and pension funds

- banks

- internal finance

- the construction industry

- property companies

- government.

Also, some developers can raise debt or equity capital directly from retail sources (small and individual investors).

The way Ratcliffe et al. (2009) categorise finance types illustrates their diversity and range:

- $\quad$ sale and leaseback

- turnkey

- general funding facility

- term loans

- overdrafts

- standby commitments

- syndicated loans

- securitisation and unitisation

- non-recourse and limited recourse loans

- joint ventures and partnerships

- venture or private capital

- mezzanine finance

- deep discount and zero coupon bonds

- hedging techniques

What the literature lacks is a case that connects various sources and types of finance with outcomes; an overview of the ways this might occur, together with an agenda to investigate these connections. Little is documented about the ways development is financed in Australia and even less of the consequences for cities. And so the research question this paper now turns to is: Is there a case that the source of finance and its type affect the built environment in Australia?

We make our case with a few examples. 


\section{Finance Sources and the Built Environment in Australia}

At the end of the 1990s the Australian financial system became one of the more regulated in the world and key financial institutions become relatively conservative: partly a response to financial collapses and excesses of the early 1990s (Davis, 2011). 96\% of the value of assets of deposit taking institutions (i.e. Banks) lies within the prudentially regulated sphere (Davis, 2011, p. 310). This feature is one often used to explain the relative resilience of the national economy and financial system to the effects of the GFC.

Nevertheless, due to the innovative and competitive nature of the property and finance industries, a considerable but unknown volume of development is financed via less regulated indirect methods such as Managed Investment Schemes (MIS) or "funds", where investor protection is reliant on the quality of information in disclosure statements and caveat emptor ${ }^{1}$. The competition for return on capital, combined with a strong real estate market prior to the GFC lead to an explosion in these types of schemes. This ready availability of funding fuelled the real estate boom, enabling high-risk projects that did not meet traditional bank lending standards, to commence.

Table 1 demonstrates the explosion in property finance providers in Australia immediately before the GFC and the few remaining players after the GFC. Drawn from a financial consultant's presentation, the table should be seen as indicative only and as a point in a continual temporal dynamic. It shows, nevertheless, that the GFC impacted severely on both the number and types of sources of property finance (Table 1).

Table 1: Changes in Development Finance Lending 2007 - 2009

\begin{tabular}{|c|c|c|}
\hline \multicolumn{2}{|c|}{$\begin{array}{l}\text { Active property finance lenders } \\
\text { in } 2007 \text { (Pre GFC) }\end{array}$} & $\begin{array}{l}\text { Active property finance lenders } \\
\text { in } 2009 \text { (Post GFC) }\end{array}$ \\
\hline 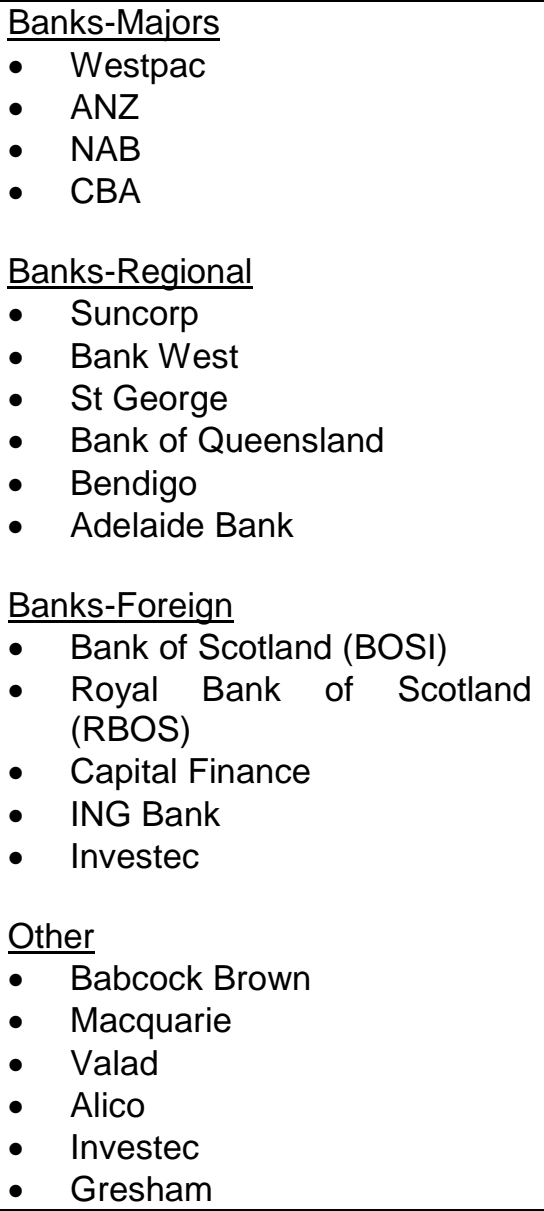 & $\begin{array}{ll}\text { Debenture Lenders } \\
\text { - } & \text { CityPacific } \\
\text { - } & \text { MFS Premium Income Fund } \\
\text { - } & \text { Octaviar (formerly MFS) } \\
\text { - } & \text { Elderslie Finance } \\
\text { - } & \text { Hanover Finance } \\
\text { - } & \text { Asset Loans } \\
\text { - } & \text { First Capital } \\
\text { - } & \text { Hastings Capital } \\
\text { - } & \text { Cymbis } \\
\text { - } & \text { Secured Mortgage } \\
& \text { Management Ltd } \\
\text { - } & \text { Donavan Oats Hannaford } \\
\text { - } & \text { Bridgecorp } \\
\text { - } & \text { Fincorpoint } \\
\text { - } & \text { Seiza Capital } \\
\text { - } & \text { Australian Capital Reserve } \\
\text { - } & \text { Grenfell Securities } \\
\text { Mortgage Trusts } \\
\text { - } \quad \text { Perpetual } \\
\text { - } & \text { Australian Unity } \\
\text { - } & \text { Challenger Financial } \\
\text { - } & \text { INGFM First State } \\
\text { - } & \text { Macarthur Cook } \\
\text { - } & \text { AXA }\end{array}$ & $\begin{array}{ll}\text { Banks-Majors } \\
& \text { CBA / Bank West } \\
\text { - } & \text { NAB } \\
\text { - } & \text { ANZ } \\
\text { - } & \text { Westpac / St George } \\
\text { Banks-Regional } \\
& \text { Bank of Qld } \\
\text { - } & \text { Bendigo / Adelaide }\end{array}$ \\
\hline
\end{tabular}

The remainder of this section will discuss a number of different sources of finance and the impact these have on the built environment.

\footnotetext{
${ }^{1}$ Latin term for "let the buyer beware".
} 


\section{Banks}

Banks are the primary source of debt funding for property development in Australia. While appetite for risk is cyclical with economic cycles, the major Australian banks have remained relatively conservative lenders. This is due not only to regulation, but also an industry response to the excesses of the 1990s and a consequence of a high degree of market concentration which discourages excessive risk taking (Davis, 2011).

Banks impact on the built environment primarily because they are very selective in their lending, tending to lend only to the most established clients with the lowest risk projects (Bryant, 2012). This selectiveness intensified with the GFC as banks became acutely risk averse and perceived themselves to be overexposed to the property markets. In the immediate aftermath of the GFC, whilst the major banks dominated the available sources of development funding from within Australia, their lending conditions re-calibrated to reflect the global credit crisis (Table 1; Bryant, 2012).

Foreign banks withdrew from the Australian market to repatriate capital to their core businesses back home While active in Australia immediately prior to the GFC, foreign banks retreated rapidly from lending to Australian developers and they originated the vast majority of non-performing loans (Table 1; APRA, 2011, Table A3; APRA, 2012, Figure 13). However, in the higher than usual conservative current lending climate of Australian institutions, Australian developers are presently actively seeking out international institutions which may prove to have a higher appetite for risk.

The nature of Banks' risk aversion extends further than just which projects can or cannot obtain finance, and hence get built. Banks also exercise considerable control over their funded projects and what is actually built through conditions such as pre-sale requirements, market research reports, approval of the selection of consultants, the inclusion of the bank's consultants in project control group meetings, setting maximum loan size limits effectively funding smaller projects only or by insisting on the redesign of developments, for example, so that large projects be broken down into smaller stages.

This credit restricted environment affected the built environment post GFC by re-shaping the development industry structure with many developers exiting the industry, having lost invested capital and being unable to source bank or other funding.

Overall then, there is an impact on how much is built, what, and by whom. This dynamic does change over the course of an economic cycle as has been demonstrated in recent years. Because the few remaining lenders have re-calibrated their lending criteria, the GFC had a built environment impact by:

- Sector: lending for residential developments only and for the best ones only

- Scale: maximum loan sizes or client exposures,

- Geographically: in prime metropolitan locations only; and

- Developers: strong track record, sufficient capital backing and good credit rating only (Bryant, 2012).

In Australia, borrowing from a bank, except for the period immediately prior to the GFC, favours projects that are relatively short-term; by established developers; that have planning approval and that are conservative, rather than innovative, by nature.

\section{Superannuation Funds}

A significant feature of the Australian financial system is the important role of superannuation (pension) in national savings relative to other countries. Employer superannuation contributions have been compulsory in Australia since 1992 and a major source of national savings (APRA, 2007). At the end of 2010, superannuation funds accounted for $20 \%$ of the assets of Australian financial institutions, with Australia having the fourth largest superannuation funds management sector in the world (Davis 2011, pp. 311 \& 320). Institutionally managed superannuation funds generally hold up to $15 \%$ of their assets in the property sector. Yet it remains to be seen to what extent and via what intermediaries these funds find their way into the built environment, and what effect this has on the form, location and scale of development.

Superannuation funds can be categorised as institutional (or wholesale) lenders or retail ("mum and dad") lenders with the latter investing via self-managed superannuation funds (SMSF). However, neither category are listed in the above table of development finance lenders. Consistent with Davis' $(2011$, p. 320) 
observation, much of their investment probably occurs indirectly rather than acting as financial intermediaries themselves.

Significantly, superannuation is a matter of some anxiety for many people - whether people have enough super savings is a common theme of the press, for example. There are numerous $-428,000$ at the end of 2010 (Davis 2011, pp. 319-20) - small, mostly self-managed funds (SMSF) accounting for roughly a quarter of superannuation fund assets. Many of these SMSFs are run with the assistance of financial planners and investments made according to the advice and recommendations provided. The savings of small (retail) investors are thus being channelled into higher-risk managed investment schemes (MIS) that are marketed via financial planner networks, where the planner receives a fee for referral and the investor bears all the investment risk. Whilst MIS' are regulated under the Australian Securities and Investment Commission (ASIC), the risks to the retail investor are blurred and there have been many cases of disastrous results to the investor (eg Long, 2007). SMSFs often invest in either debenture/mortgage trusts or development funds (raising either or both debt and equity capital). Both of these will be discussed separately later.

On the other hand, the situation is dynamic post GFC with large institutional superannuation funds selectively chasing the higher returns available from large scale development. We observe presently emerging instances of superannuation funds forming funding alliances with developers, or actually becoming the developer themselves (eg CBUS Development, Colonial Super investment). This trend is due to competition amongst the large superfunds for above market returns, being matched with developers unable to access larger loans (debt) from the traditional banks at terms for which projects are economically viable.

Historically, instances do exist of large superannuation funds investing directly in long term development projects either as debt or equity investors. Flagstone, for example, a city with a target population of 160,000 in south east Queensland is an initiative of MTAA Superannuation that dates back to the 1980's. Originally planned to accommodate 50,000 residents, in 2011 MTAA formed a joint venture with one of Australia' largest publicly listed developers PEET, a partnership which enabled a complete redesign of the project, brought in relevant expertise and necessary capital. (McIntyre, 2011). This project is consistent with Ratcliffe et al.'s (2009, p. 431) observations that pension funds are a source of long term funding, a foreign characteristic for traditional property finance which is generally short term in nature.

\section{Debenture Lenders and Mortgage Trusts}

Debenture lenders and mortgage trusts are innovative lending instruments that for the purpose of this discussion are essentially similar in nature: capital is raised from retail investors by finance companies via the issue of debentures (unsecured) or units in a mortgage trust (secured) respectively. These funds are then on-lent to developers via the finance company. These products are marketed as a debt instrument often secured by way of second or other subordinated mortgage.

Sometimes the distinction between the finance company and the developer is blurred or not-existent being linked by associated companies. The retail investors often are unsophisticated and self-managing their retirement funds and savings, with or without the advice of financial advisors. This activity occurs (largely) outside of the prudentially regulated sector and there has been a matter of some public debate and calls for further regulation of the finance companies in the same manner as banks (Australian Broadcasting Corporation, 2013; Klan, 2013). During the GFC, these lender groups suffered terminal losses as property prices tumbled and investor money was lost.

The press reports similar funds (termed securitisation) in 2000s as an emerging mechanism to fund largescale specific development projects in Australia for large scale established developers such as Australand (Anon, 2002). These deals were arranged by intermediaries like the ANZ bank who issued asset backed securities that were risk-rated by independent agencies like Moodys. The deals were of significant scale raising amounts of capital in the low hundreds of millions of dollars. For the arranger, the benefits were lowrisk fee earnings with the lending risk carried by the investors: the Australand deal involved six investors, mainly investment managers. For the large corporate developer this is a way of funding high value projects such as large apartment towers which cannot be easily broken down into smaller lower-risk stages. The method requires considerable ground-work by the developer in order to make the investment attractive: this Australand apartment project was backed by around $80 \%$ pre-sales with firm contracts.

As indicated above, many - i.e. around half - of these funds failed during the GFC years. One recent report indicates that by 2013, 24 out of 49 mortgage funds identified by ASIC in 2007 as unlisted property-related debenture funds collapsed losing $\$ 2$ billion of mostly small investors' savings (Klan, 2013). By Abraham and 
Holden's account (2009) these funds dried up as a source of development funding immediately after the GFC (Table 1 and Bryant, 2012). However, more recent sources indicate that those surviving finance companies have now re-entered the market (some re-branded), and that new debenture/mortgage funds are re-emerging (Anon, 2013). In any case, the appetite for non-bank development funding, combined with the quest for high returns on capital and a facilitatory regulatory environment continue to create opportunities for such debenture lenders. Indeed, unsophisticated small investors continue to lend despite the risks and institution failures (Klan, 2013).

The blurred distinction between developer and finance company is evident in the case of three developers which collapsed just before the GFC - Fincorp, Westpoint and, Australian Capital Reserve - all identified as debenture lenders in Table 1 (Brown, 2007; Glanville, 2007; Klan, 2007; Maiden, 2007) which marketed the investment opportunity to retail investors via financial planner networks. These three funds alone accounted for about $\$ 1$ billion combined losses from about 20,000 investors. The average investor age in one of these funds was 60 (Klan, 2007), indicating a high proportion of superannuant participation.

The risks to investors in these MIS' are often opaque, muddied by factors including: the quality of the product disclosure statements; vested interests of related parties; the reliability or otherwise of project valuations; the independence and quality of advice of financial planners; the sophistication or otherwise of the investors often self-funded retirees; and especially the shifting of the onus of risk assessment from the institution to the retail investors via reliance on caveat emptor through product disclosure documentation. Whilst debenture/mortgage funds can be a legitimate source of development finance, as well as a high yielding opportunity for investors, the public and spectacular failings of these finance companies is likely to limit investor appetite in these products in the foreseeable future.

Outcomes for the built environment from debenture/mortgage fund lending can be dire. This funding model thrives in a booming market where high risk projects can be structured to look attractive to return hungry investors. These risky projects which might not otherwise get started, are executed by developers who might not otherwise get funded from traditional (bank) sources due to a number of factors including: lack of experience or poor credit history; lack of personal equity to invest in the project (or unwillingness to do so); or high interest rates on higher loan to value ratios that might otherwise be obtained from traditional (bank) sources - around $20 \%$ according to one recent source (Anon., 2013a). As witnessed in the post-GFC fall out these factors can come together to create a "perfect storm" to the detriment of investors and the built environment as these high risk projects fail part way through the development process. Failed projects result in derelict sites or partially completed projects that are overcapitalised. Significant price reduction and losses to investors are the result, as is lengthy litigation. Years may pass before development is again viable on these derelict and underutilised sites.

\section{Development Funds}

The establishment of a project-specific development fund is another financing option that may be available to larger scale, experienced developers. Development funds gather savings from retail or wholesale investors via an intermediary company either established by the developer or a third party arranger. This form of funding is also a MIS for the purposes of ASIC regulation; however it differs from debenture/mortgage trusts in two key areas: it generally raises equity (higher risk and unsecured) rather than debt, and the funds are raised for a specific project making it a more direct form of investment.

One developer that is active in the development fund sector is Peet Corporation. The publicly listed developer claims to have pioneered what they (technically erroneously) call syndicated funding. The details of some of Peet's activities are illustrated in Figure 1. 


\section{Profile of a Pioneer of "Syndicated Funding" - Peet Corporation}

- Self described as a "leading land estate developer and property fund manager" with 150 employees in Perth, Brisbane and Melbourne.

- Established as a real estate agent in the 1890's in Perth and expanded into development

- Became a publicly listed development and property corporation in 2004

- Has a land bank with a potential for 48,500 potential residential lots with an estimated completion value in $2012 \$ 8.8$ billion in 2012 prices. This is the third largest residential land bank of 10 ASX listed developers.

- Pioneered syndication in Australia in the 1990s

- Currently manages 22 syndicates to fund 25 residential land development projects

- Using syndication, Peet has, since 2003 , raised $\$ 290$ million for projects with a completion value of $\$ 2.5$ billion in 2012 prices.

- A current 'syndicated land acquisition' involves raising $\$ 17 \mathrm{~m}$ for the development of about 437 lots in Greenvale on Melbourne's northern outskirts. Capital is raised by the sale of PEET's development site to a managed investment fund, "Peet Greenvale Syndicate". The Syndicate, registered on the 12th November 2012 is offering one million units of \$1 each until the 14th March 2013. Peet estimate the project completion time at 6 years.

- Had a total of 68 development projects in four Australian states in 2012 comprising, syndicated projects, managed projects, Peet owned projects, and joint ventures.

Source: Peet, 2012; Peet webpage

This allows a firm to diversify its capital base and risks and to expand into additional projects that it would otherwise have trouble funding. It is an avenue to capture additional market share, fee based income and development profits without adding to risk (some risk is transferred to retail investors); to raise its profile and reputation; and obtain longer-term funding.

Built environment impacts from development funds can be the same as those for debenture/mortgage trusts. Whilst on one hand they can facilitate development in the absence of sufficient traditional debt funding, their success is largely dependent upon the track record of the developer and the quality of the project. Hence it is not generally a method of funding available to new market entrants.

\section{Self Funding - Private Equity}

Whilst corporate finance principles dictate it is better to risk someone else's money, self-funding does exist, either occasionally as the sole source of funding, or one larger than usual tranche in the funding equation. This category actually embraces a range of disparate approaches often measuring its return on desired outcomes other than just equity invested. There are, for instance, individuals and organisations of diverse backgrounds which, having acquired wealth by various means, use it to make a mark one way or another. This impact on the built environment can be remarkable. Consider for example the Gold Coast panorama of golf course estates and luxury hotels is the result of poorly conceived, poorly or not well evaluated projects for which there was little or no market, executed by an unlikely succession of assorted industrialists, actors and others including Japanese neo-developers made wealthy by the revaluation of the Yen in the 1980's and blind to the risks of development (Hajdu, 2005). The Gold Coast is also, however, home of some of the most celebrated environmental innovations in development - Couran Cove and the Currumbin Eco-Village to name two, that were enabled by independent backing willing to take a risk that conventional sources would not have done at that time (Coiacetto 2009).

\section{Corporate Finance - Trading Debt and Public Equity}

Consider on the other hand, large scale publicly listed diversified property corporations. How these allocate capital (equity) to their development projects is rarely the subject of scrutiny. Many publicly listed companies use a variety of funding approaches to spread the funding risks (eg the Peet example in Figure 1). In contrast to private developers who secure short term finance on a project by project basis, larger public property firms have access to a range of longer term funding options. These funding options include trading debt facilities which have longer terms and lower interest rates; issue of commercial debt securities (secured against income producing assets); as well as access to public equity via share capital. Allocation of capital 
internally is then managed via an internal treasury function with group reporting to banks on overall company performance. A private firm normally would not be large enough and have sufficient diversification in its income stream to access these sources of funding or to carry the requisite internal overhead associated. .

But long-term access to cheaper capital shapes the capacity of such organisations putting them in positions, amongst other things, to plan and execute long-term projects and strategies; to absorb the vicissitudes of the property cycles; to grow large enough to spread risks across multiple locations, sectors and sub-markets; to engage with and influence regulation and politics at a sustained and high level; to be less reliant upon the conditions and controls of project finance lenders; and to build wealth through retention of a portfolio of income producing assets. Importantly, it also affords them the power, means and status to devise or access a variety of forms of funding that are to their advantage and cheaper such as via on or offshore debenture issues, and various forms of public or private equity raising. It also affords them the bargaining power to negotiate favourable debt funding deals with financial institutions like banks. In this way, large public developers can access cheaper capital by issuing corporate bonds overseas, or raising equity from public shareholders seeking modest "low risk" returns such as on REITs (around 8\%). Private developers on the other hand cannot access such cheap debt and must pay a premium for equity (around 20\%).

Hence the weighted average cost of capital is much lower for big public developers (say 12\%), enabling them to be more competitive when bidding for sites and securing new projects. How such developers undertake financial feasibility assessments of projects when funded by multiple debt and equity avenues is a subject to investigate.

Larger scale developers execute the largest master planned communities in most Australian cities. In the South East Queensland case, entirely new towns - Springfield, Ripley, Yarrabilba, Flagstone and Caloundra South - are each being built by individual developers over timeframes of a couple of decades. While many small and mid tier developers have been forced out of the industry due to financial hardship, large and publicly listed firms have survived the GFC relatively intact, albeit adversely affected by asset write-downs, disposing of poor performing projects, or in other ways corporately wounded (Anon ,2013b; Carter, 2013; Cranston, 2013; Cummins, 2013).

In the current financial climate, the broader, longer-term and cheaper funding opportunities for large developers relative to small scale developers is manifesting in the built environment in other ways as well. Notably, it creates a problem for urban planners to achieve urban consolidation targets: smaller infill projects are not proceeding simply because the small-scale innovative developers necessary to deliver on smaller, challenging brownfield and greyfield sites are reliant on high levels of debt funding from banks and do not have access to the requisite levels of equity. By contrast, the large-scale greenfield operators with standardised development templates and better access to the debt and equity markets are the current dominant producers of new residential lots and are perpetuating urban sprawl.

If access to cheaper longer-term capital delivers some developers a position of power with which to negotiate with financier, regulators and politicians, some other self funded operators lack such power. Ruming (2010) found that - relative to middle and larger scale developers - the many small, sometime once-only, often selffunded operators responsible for much of the infill development in Sydney's middle ring suburbs show little capacity or aptitude for negotiating or mobilising informal associations with councils. On the other hand, such self funding may be the only way that many small developments can get built, even if their quality is questionable (Coiacetto, 2001; 2000).

\section{Conclusions}

Whilst only a few forms of financing were discussed in any detail here, the above examples are suffice to demonstrate that there is a case that the nature of development finance has an impact on the built environment and that this is a significant matter worth pursuing. The flow on effect to the built environment from various forms of funding development includes:

- the nature of the development organisation and source of finance (in a two way relationship where the nature of the development organisation affects the type of finance they can obtain and vice versa)

- how developers operate and what projects they can proceed with

- the autonomy and degree of control developers have over their projects

- what developers can build and how many projects they can undertake; for whom, where and at what priced product 
- the scale and time frames for projects

- the level of risk developers can take, and

- the potential for innovation.

Some key questions then are:

What are the ways that development is financed in Australia? How do these change over short-term development cycles and what new ways are developed over longer time frames? What is the relationship between the method(s) of funding and the nature of the development organisation eg its stability; public or private; reputation; mode of operation; ways of dealing with community and regulators; product and market sector? How do specific types and sources of funding - superannuation funds or international institutions, for example - shape the built environment? How does the funding in conjunction with the nature of the organisation funded by that mode combine to produce built environment outcomes? How do they variously affect attributes of the development and development products including the cost; price; the quality; the location; form and scale? In other words, do inter-firm differences in funding sources and methods lead to differences in their projects and product, and if so, how and why? Where an individual firm uses different means to fund different projects (eg Figure 1), do those projects differ as a result of those funding differences and if so, how and why?

But there are also important policy-related questions and implications. Factors and policies outside the ambit of formal urban policy and planning have a relatively greater (unintended) impact on shaping cities than do formal urban policies (Tomlinson 2012). Tomlinson and Burke's chapter therein (Tomlinson and Burke, 2012), makes a clear case for this in relation to the impact of the de-regulation of the Australian home mortgage industry on housing in Australia, it's price in particular. The key relevant policy questions then become:

- to what extend do neo-liberally inspired realignment of finance policy shape urban outcomes via its impact on development finance?

- how do finance and finance policy, as factors, compare in impact on urban outcomes relative to the impacts of formal urban policy? and

- what scope is there to shape urban outcomes by using financial policy as an instruments to shape the decision making of developers (Adams and Tiesdell 2013).

As demonstrated, the question of "How does access to development finance shape our cities?" is a complex one. The development finance environment is constantly changing through short-term cycles and longer term structural shifts. Firms and institutions constantly enter and leave the market, risk appetites come and go, as does competition for investment return. Access to data, where it exists, may prove difficult where matters are sensitive and/or confidential and organisations opaque. Methodologically, therefore, answering such questions is likely to present a significant and interesting challenge for further research.

\section{Acknowledgements}

We wish to thank the anonymous referees whose comments helped to improve this paper.

\section{References}

Abrahams, A. \& Holden. D. (2009) Finding the Money. Powerpoint presentation by Ashe Morgan Winthrop Specialized property finance and investment group. Available at $<$ http://www.sdgci.com.au/assets/pdf/Alton-Abrahams-pp.pdf> sourced 25/1/2011.

Adams, D., \& Tiesdell, S. (2013). Shaping Places: Urban planning, design and development. Abingdon: Routledge.

Adams, D., Croudace, R., \& Tiesdell, S. (2012) Exploring the 'notional property developer' as a policy construct. Urban Studies, 49(12), 2577-2596.

Adams, D. (1994) Urban Planning and the Development Process (UCL Press Limited, London).

APRA (Australian Prudential Regulatory Authority), (2007) A recent history of superannuation in Australia, In APRA Insight, Issue Two 2007 Special Edition, Available at http://www.apra.gov.au/Insight/Documents/History-of-superannuation.pdf sourced 12/4/13. 
APRA (Australian Prudential Regulatory Authority), (2011) Statistics, In APRA Insight Issue 12011 , Available at http://www.apra.gov.au/Insight/Documents/Insight_issue_1_2011_all.pdf sourced $12 / 4 / 13$

APRA (Australian Prudential Regulatory Authority), (2012), ADI Industry Risks, In APRA Insight Issue 2 2012, Available at http://www.apra.gov.au/Insight/Documents/Insight_issue2_2012V7.pdf sourced $12 / 4 / 13$

Anonymous (2013a). Self-funded retirees facing $\$ 30$ million losses following collapse of lender Wickham Securities. Property Observer, Tue 22nd January.

Anonymous (2013b) Stockland selling poor residential assets. news.com.au , 13th Feb. Accessed 27th Feb 2013.

Anonymous (2002) ANZ brings Australand ABS of new property development. EuroWeek 16th August.

Australian Broadcasting Corporation. (2013) A Betrayal of Trust. Four Corners (TV Broadcast), Monday 4th March (Stephen Long Reporter). Australian Broadcasting Corporation.

Ball, M. (1998) Institutions in British property research: a review. Urban Studies, 35(9), 1501-1517.

Brown, Helen. (2007) Investment group Australian Capital Reserve collapses. Lateline (TV Broadcast) 29 Mar 2007, Australian Broadcasting Corporation.

Bryant, L. (2012) An assessment of development funding for new housing post GFC in Queensland, Australia. International Journal of Housing Markets and Analysis, 5(2), 118-133.

Carter, Bridget. (2013) Mirvac takes $\$ 273 \mathrm{~m}$ hit with Stockland to follow. The Australian: Finance, 8th Feb, p. 19.

Coiacetto, E. (2000) Planning-in-practice and Planning-in-principle: Is planning facilitative of the real estate development process? Australian Planner, 37(3), 120-129.

Coiacetto, E. (2001) Diversity in Real Estate Developer Behaviour: A case for research. Urban Policy and Research, 19(1), 43-59.

Coiacetto, E. (2007) Residential sub-market targeting by developers in Brisbane. Urban Policy and Research, 25(2), 257-274.

Coiacetto, E. (2009). Gold Coast development: A special case or same old city factories? . Refereed paper presented at the State of Australian Cities Conference 2009, Perth.

Coiacetto, E. (2012) Understanding Land Development: A project-based approach (CSIRO, Collingwood).

Coiacetto, E. \& Baker, D. (2006) Public real estate development in Queensland: Local Government as developers. Urban Policy and Research, 24(2), 237-252.

Craniston, Matther. (2013) Mirvac warns on Qld projects. Financial Review: Companies and Markets, 9th Feb. p. 40.

Cummins, Carolyn. (2013) Developer set to prune projects. Canberra Times, Feb 11.

Davis, K. (2011) The Australian financial system in the 2000s: dodging the bullet. In H. K. J. Gerard (Ed.), The Australian Economy in the 2000s (pp. 301-353). Sydney: Reserve Bank of Australia.

Fainstein, S. F. (2001) The City Builders: Property Development in New York and London, 1980-2000 (2nd ed.) (Lawrence, University Press of Kansas). 
Foley, P. \& Hutchison, J. (1994) Planning application as primary data source - Industrial development in Sheffield 1978-1991. Area, 26(2), 123-132.

Glanville, Brigid. (2007) Finance industry fears further collapse of property developers. Lateline Business (TV Broadcast), 29 Mar, Australian Broadcasting Corporation.

Gleeson, B. \& Coiacetto, E. (2007) Positive planning in Australia: a review of historical and emergent rationales. Urban Policy and Research, 25(1), 5-19.

Hajdu, J. (2005) Samurai in the Surf: The Arrival of the Japanese on the Gold Coast in the 1980s (Canberra, Pandanus Books).

Klan, Anthony. (2013) Collapses dismissed as millions flow to mortgage funds. The Australian: Prime Space, 7th March, p. 29.

Klan, Anthony. (2007) Savings at risk after Fincorp collapse. The Australian. (March 26th)

Logan, J. (1993) Cycles and trends in the globalization of real estate. In P. L. Knox (Ed.), The Restless Urban Landscape. (pp. 35 - 54.). (Prentice Hall: Englewood Cliffs, New Jersey).

Long, S. (2007) Investors hit hard by Bridgecorp collapse, Australian Broadcasting Corporation, PM Tuesday, 3 July, 2007, Available at http://www.abc.net.au/pm/content/2007/s1969049.htm sourced $12 / 4 / 13$

Maiden, Malcolm (2007) Aggressive attack needed after ACR collapse. The Age, May 30, Business Section.

McKenzie, E. (1994) Privatopia: Homeowner Associations and the Rise of Residential Private Government (New Haven, Yale University Press).

McIntyre, Ashleigh (2011). MTAA partners with residential developer Peet. Super Review, June 2nd.

Peet (2012, 19th November) Product Disclosure Statement: Peet Greenvale Syndicate, ARSN 160996 510. (133 pages). Perth: Peet Funds Management. Accessed at http://www.peet.com.au/Investing/Syndicate\%20Investments/greenvale.aspx on 18th Feb 2013

Peet (webpage) A history of Peet. Accessed at http://www.peet.com.au/About\%20Peet/History.aspx on 19th Feb 2013

Ratcliffe, J., Stubbs, M., \& Keeping, M. (2009) Urban Planning and Real Estate Development (3rd ed.). (London, Routledge).

Ruming, K. (2011). Creating Australia's best planning system? Private sector responses to NSW planning changes. Australian Planner, 48(4), 257-269.

Sharam, A., McShane, I., Alves, T., Bryant, L. \& Shihab-Smith , A. (in review) Applying market design theory to 'greyfields' housing supply.

Tomlinson, M., \& Burke, T. (2012). Household debt: mortgage lending practices and the housing market. In R. Tomlinson (Ed.), Australia's Unintended Cities: The Impact of Housing on Urban Development (pp. 69-82). Collingwood: CSIRO.

Tomlinson, R. (Ed.). (2012). Australia's Unintended Cities: The Impact of Housing on Urban Development. Collingwood: CSIRO. 